\title{
Made In China 2025 and New Trends of Entrepreneurship Education of China: A Socio-Economic-Educational Perspective
}

\author{
Hongyun $\mathrm{Wu}^{1} \&$ Spencer A. Benson ${ }^{2}$ \\ ${ }^{1}$ The School of Public Affairs, University of Science and Technology of China, Hefei, China \\ ${ }^{2}$ Centre for Teaching and Learning Enhancement \& Faculty of Health Sciences, University of Macau, Taipa, \\ Macau, SAR, China \\ Correspondence: Hongyun Wu, The School of Public Affairs, University of Science and Technology of China, \\ Hefei 230026, China.
}

Received: November 19, 2016

Accepted: December 12, 2016

Online Published: December 27, 2016

doi:10.20849/aes.v2i1.103

URL: http://dx.doi.org/10.20849/aes.v2i1.103

\begin{abstract}
The importance of entrepreneurship for economic growth and job creation has gained wide acceptance around the world. The Chinese government is dedicated to innovation and entrepreneurship, realizing the critical importance in meeting this dual purpose lies in entrepreneurship education (EE) and its integration across the government, academic and business sectors. This paper outlines the emergence of entrepreneurship and the emerging trends in EE of China by looking at the past and present of China's economy, education and government policies through a socio-economic-educational perspective. It focuses on Made In China 2025, an important 10-year national plan, that outlines China's objectives in future economic development, and the future directions for China's EE. By looking at past and emerging trends this study presents a historical and current picture of EE within China. The socio-economic-educational perspective of this study results in the following observations: the change from government programmed economy to a more open briskness driven economy, the close relationship between China's reform in economy and education, the impact of government policies and mandates on China's entrepreneurship education, EE in China, a new facet of China's education reform, which has moved from education for the elite to the masses, and lastly, Made In China 2025's call for innovation and reform in educational practices of EE in China. The application of a socio-economic-educational perspective provides for broader and deeper insights into the direction for the further development of $\mathrm{EE}$ in China.
\end{abstract}

Keywords: entrepreneurship education, socio-economic-educational perspective, Made In China 2025, higher education reform

\section{Introduction}

Since 1978, when Deng Xiaoping came to power as the leader of Chinese central government, the government has focused on reform and opening up to the outside world. China's reform involves nearly every aspects of the society, including the two critically important fields: economy and education. On May 19, 2015 the Chinese central government issued Made In China 2025(Ministry of Finance of the People's Republic of China[MOF], 2015), "the first phase of an ambitious 30-year goal that is under the direct supervision of Premier Li Keqiang" (Gao, 2015, para.3), and a cornerstone document in economic reform as China enters a new stage of world leadership. The Made In China 2025's impact goes beyond the economic sector to the educational realm, and involves references to education reform including EE in China.

More than two decades has passed since the concept of EE was first introduced into China in 1989 (Li \&Liu, 2009; Liu \& Jia, 2011; Huang \& Zhao, 2015). Till the early years of this century, it was described as "lingered in its formative stages" (Li, 2002 as cited in Li, Zhang, \& Matlay, 2003, p.496). During the preliminary stage it experienced several bottlenecks, which mainly occurred from a lack of clear understanding of the objectives and motives as well as its future directions (Liu \& Jia, 2011; Shi, 2013; Liu, Xu, \& Liu, 2007). With the implementation of Made in China 2025, however, the importance of EE in China once again has become prominent. However, as a new facet within China's education reform movement, the question of future directions remain open. Made in China 2025 is not only a blueprint for the national economy, but also a strategic guideline for EE in a new era. Combining text analysis with socio-economic perspective, the article demonstrates that the future direction of China's EE depends on and must be in line with the basic demand for in-depth 
economic reform, in alignment with the Made in China 2025 strategy. Based on an analysis of the correlation between Made in China 2025 strategy and China's EE, the article further explores new trends in EE in China. The first part of the article reviews important historical developments and policies during the process of China's economic reform. The second part discusses the importance and uniqueness of Made In China 2025 as a new milestone in present-day China's economic reform. The third part introduces China's educational reform and the current situation of EE, a new sphere of the educational system reform. The fourth part examines the influence of Chinese central government policy on the development of EE in China. The final part illustrates new trends in China's EE.

\section{Economic Reform in China: Past and Present}

\subsection{Past Critical Developments in China's Economic Reform}

Since 1978 when the Central Committee of the Communist Party of China (CCCPC) led by Deng Xiaoping launched preliminary experiments on economic reform, numerous policies have been implemented to develop the national economy. There are guidelines for economic reform in different historical periods. Before 2015 when Made In China 2025 was issued, the following important developments in the history of China's economic reformation are worth mentioning occurred in the period 1978 through1992.

In 1978, the 3rd Plenary Session of the 11th CCCPC initiated China's experiment in economic reform of rural areas "with the introduction of the family responsibility system", which results in the "rapid development of township and village enterprises" (Li et al., 2003, p.497). Starting in the1980s, the CCCPC focused on economic development of the urban areas through experiments on initiating a market economy and establishing special economic zones, among which Shenzhen, Zhuhai, Shantou, and Xiamen were the first four cities. In 1984, 14 coastal cities with support and approval by the central government to open up economically. The government further expanded similar economic experiments to larger areas, e.g. three coast triangle economic development zones along the Yangtz River, the Pearl River, and Xiamen, Zhaozhou, and Quanzhou along Minjiang River. In 1988, the province of Hainan was established as a special economic zone.

The industry and manufacturing sector has undergone great changes beginning in1978 when the priority of China's economic development began to shift gradually from heavy to light industry. The gross industrial output of state owned enterprises, mainly heavy industry, grew slowly during this period while that of non-state owned sectors began to grow at a faster pace. (Huang, 2008) However, it is not until 1988 when the $7^{\text {th }}$ National People's Congress passed the constitutional amendment to legalize the existence of private owned businesses that private owned businesses were legally acknowledged. Due to the restriction of a deeply-rooted planned economy system, the private industrial sector did not see any significant breakthroughs before 1992, the year that is historically important both for the Communist Party and the national economy of China. In the spring of 1992, Deng Xiaoping's "Southern Talk"(Liang, 2014, p.18) was published following his tour of four major southern cities in China. Deng's talk strengthened the people's belief and confidence for further development of a socialist market economy, and hence paved the way for a period of rapid economic growth. Thus, it is not surprising that the Eighth Five-Year Plan (1992 to 1997) was realized ahead of the schedule for the goal of doubling GDP which was originally set to be achieved in the year of 2000. (Wu, 2009) The growth rate of GDP was as high as $10.4 \%$ during the ten years from 1990 to $2000(\mathrm{Li}, \mathrm{Wu}, \mathrm{He}, \& \mathrm{Liu}, 2012)$.

\subsection{New Milestone of Economic Reform in Present- Day China: Made In China 2025}

\subsubsection{What Is Made In China 2025?}

Continuing into the 21 st century Chinese central government's consistently focused on comprehensive and in-depth economic reform, and China has become the second largest economy following the US. The second decade of the 21st century, brought new changes in China's economy. As a result of economic downturn in 2015, when the economic growth rate dropped to 6.9\%, the lowest level in 25 years (Chuan, 2016), the central government developed to a new economic model to pursue a policy of quality development of the national economy, boosting a balanced development__ integrating the people's demand for social services e.g. better health, education, housing, and environment into a comprehensive development model, which is known as "The New Normal Model (under China's circumstance)" put forward by president Xi Jinping in 2014 (Jin, 2015, p.8). The result being, China's economic policy now is focusing on the quality of economic growth instead of simply volume.

Made In China 2025 (also called Made In China 2025 strategy) is a testimony of the economic structuring strategy of the current central government, and a new milestone in China's economic reformation under current national and international circumstances and constraints. It is "clearly designed to transform China from a 
manufacturing giant into an international manufacturing superpower" (Trentini, 2015, para.1). Made in China 2025 , the first ten-year plan, outlines the nation's goal of being a leading world manufacturing superpower within 30 years. This economic blueprint highlights the nation's focus on world market competition is shifting from petty commodities to high-tech products. This change is supported by recent statistics that show an emerging trend in China's manufacturing sectors. The National Bureau of Statistics (NBS) announced in August 2015 industrial output rose by 6.1 percent year-on-year, while high-tech manufacturing grew by 10.2 percent year-on-year (The State Council Information Office of the People's Republic of China, 2016). In April 2016, both Reuters and Asian Times reported that the official Purchasing Managers' Index (PMI) rose to 50.2 in March, up from February's 49 (Asia Unhedged, 2016; Taplin \& Sweeney, 2016).

\subsubsection{Features of Made in China 2025}

Compared with former economic reform policies, Made in China 2025 has a number of prominently different features. First, it is a manifestation of Chinese leadership's perception of the necessity for a strategic shift in order to carry on economic system reform from being "a manufacturer of quantity to one of quality" (Shi, 2015, para.2). Made in China 2025 authorized by Premier Li Keqiang (Trentini, 2015) was drafted over a two-year period with input from more than 150 experts, and focuses on 10 priority industries, and four key ministries, including the Ministry of Industry and Technology (MIIT). The aim of the plan is to optimize economic structure including continuing to encourage private owned businesses, especially the SMEs (small and medium enterprises), which are proven to be one of the drivers of China's growth (Orszag, 2014), and a major contributor of employment in China (Zhao, 2012). Mr. Wu Jinglian (2010) argues: "It is not the growth rate but the growth pattern of the economy that is linked to employment" (as cited in Cao, 2012, p.234). The government policies to encourage and support SMEs' development is conducive to the shift of economic growth pattern, and therefore effective for addressing current and future employment issues.

Second, Made In China 2025 aims to promote the international competitiveness of Chinese manufacturing in lieu of simply increasing the gross product amounts which was a basic tenant of former plans. The document outlines the development of cutting-edge techniques, such as advanced information technology, automated machines and robotics, aerospace equipment, new materials and biomedicine. Its goals are to jump start China's fourth industrial revolution and enable China to compete with advanced manufacturing powers such as the US, Germany and Japan (Deloitte, 2016). Third, it emphasizes the importance of independent innovation in manufacturing and development. According to Li Beiguang (2015), deputy head of MIIT planning division, "There are many criteria to judge whether a country is a manufacturing power or not...but the key lies in innovation." (Li as cited in Trentini, 2015, para.3). The plan illustrates modern China's goal to be an equal partner with the leading international manufacturing powers not just to follow in their wake.

Most importantly, Made In China 2025 puts education, especially higher education, as one of the priorities necessary to boost this new vision of economic growth. This strategy differs from its former counterparts which primarily focused on economic growth rate with scarce references to education. It clearly sends the signal that China will build a sound growth of economy on the basis of a quality education. One of the guiding principles of Made In China 2025 is "talents are the foundation" (MOF, 2015, para.17) and many of the measures outlined to support the manufacturing upgrading in the plan are related to higher education institutions. It clearly acknowledges China's urgent demand for professionals in entrepreneurial management and experts in technologies and science. Made In China 2025 advocates training programs within enterprises to promote development for research, production and management. Additionally, it proposes building a multi-level talent training mechanism within higher education institutions. The importance of education and the essential nature of trained professionals is a centerpiece of Made In China 2025 in contrast to the previous plans of economic development which marginally, at best, address educational and training issues.

\section{A New Facet of Education Reform in China: EE}

\subsection{China's Education Reform}

The educational system in China especially that of higher education is in transition from the planned economy (Zhang \& Liu, 2013) to a market economy orientation. Traditionally China's higher educational system had been governed by a planned economy pattern. With the development of a socialist market economy, the planned economy oriented educational system has become increasingly inconsistent with modern Chinese society. Various government policies have played key roles in the development of education reform in China.

Thirty years ago (1985) the Chinese government launched its first complete reform in education concurrent with China's opening up to the outside world (Ministry of Education of the People's Republic of China[MOE], 1985). Reform of the educational system was a focus of Chinese central government during this period. In 1992, the 
central government of China issued The Decision of The Central Committee of The Communist Party of China and The State Council on Accelerating Development of Tertiary Industry (News of the Communist Party of China, 1992), which clearly categorized education as a tertiary industry and defined it as a part of the society's productive force (Liu, 2010). In the late 1990s the Chinese government began to reform the college admission system and increase college admission scale. According to a survey by the ministry of education of China in 2015, as of 2015 China has the largest population of college students and comes in second in terms of the number of higher education institutions (Wang, 2015). Higher education in China has undergone significant changes since the late 1990s, however, it still faces great challenges stemming from issues and developments in the 21 st century; e.g. a rising middle class, increased higher education demand, new educational technologies, new modes of information access, a demand for new types of pedagogy and increased accountability.

\subsection{EE Turns a New Page in China's Education Reform}

There's still controversy about the specific starting year of EE in China (Li \& Liu, 2009; Liu \& Jia, 2011; Huang \& Zhao, 2015; Xiong \& Qiu, 2005; Tong, 2012; Shi, 2013; Wang, 2015), however, it is evident that it began to gain increasing attention in China in the late 1990s, and has been the focus of government policies on education reform since then. As a consequence of the educational reform that increased access to college, unemployment of college graduates increased. The need to create new jobs for these graduates and for society in general is one of the reasons why entrepreneurship education has become a new direction within China's education reform. However, other aspects related to the Made In China 2025 plan also come into play in meeting the plan's strategic goals. Since 1992 sustainable development has gradually become an international consensus (Strategic Research Group of China Sustainable Development, 2015). China has committed to participating in the global sustainable development. The theme of China Sustainable Development Report 2015 is "Reshaping the Governance for Sustainable Development" (Chinese Academy of Sciences, 2015, para. 2). In recent years, social demands for more jobs, better quality of life and a better environment are on the rise, and to address these demands Chinese government perceives the necessity of restructuring the economy to make it more innovation-driven and knowledge-intensive. This requires more and diverse intelligence resources and intellectual capital including think tanks, which are primarily in the higher education sector. Meeting the practical demands and development of the society is the biggest drive and aim for China's higher education reform (He, 2012). The development of EE platforms provides means to address the above demands of the people besides its direct goal to increase employment; as such, it has become embedded in China's educational reform and development policies (Liu et al., 2007; Tong, 2012). Liming Fan, the president of Shanghai University of Finance and Economics, said: "Innovation and entrepreneurship education has not only become mandatory part of teaching and learning in Chinese higher education institutions, but also a breakthrough in higher education reform in China" (Fan, 2016, para.3).

\section{Impact of Chinese Central Government Policy on the Development of EE}

Higher education policy in China is strongly influenced and directed by central and regional governments in meeting the goals of reforming higher education to meet two mandates, social development and economic well-being. Many researchers have noted that entrepreneurial activities are significantly influenced by socio-economic and political factors (Li et al., 2003; Gnyawali \& Fogel, 1994; Gupta, 2012). Jun Li, Yuli Zhang and Harry Matlay (2003) state "China's experience of small business development in the past two decades suggests that entrepreneurship is sensitive to changes in the wider socio-economic and political environment" ( $\mathrm{Li}$ et al., 2003, p.497). In recent years the Chinese government has played a central role in the development of EE and as such it is largely "government- driven", which is different from the "need-driven" pattern of the USA and elsewhere (Yan, 2011, p.45).

As early as January 1999, the State Council approved The 1999 Chinese Action Scheme For Invigorating Education Towards The 21st Century by the Ministry of Education, which formally advocated that "teachers and students must be trained in entrepreneurship education, and they should be encouraged to set up hi-tech enterprises" (MOE, 1998, para.37). This was the first time that "entrepreneurship education" appeared in government documents. In response to this call to action, a few universities and colleges began experimenting with the teaching of entrepreneurial courses.

In April 2002, the Ministry of Education (MOE) designated Tsinghua University, Beijing University, Renmin University, Shanghai Jiao Tong University, Xi'an Jiao Tong University, Wuhan University, Heilongjiang University, Nanjing University of Finance \& Economics, and Northwestern Polytechnic University as nine universities for the development of entrepreneurship education models and provided them both policy and financial support. In 2010, the MOE issued Opinions about Vigorously Promoting Innovation and 
Entrepreneurship Education and Self-Employment in Higher Education Institutions (MOE, 2010), officially calling for innovations in entrepreneurship education. As a result more colleges and universities initiated research and innovation in entrepreneurship education including curriculum system design and teacher training. In 2012, the MOE's Opinions about All-around Improvement of The Quality of Higher Education (MOE, 2012) specified that further strengthening innovation and entrepreneurship education is one of the important direction for China's higher education reform and emphasized the key role of innovation and entrepreneurship education to comprehensively promote the quality of China's higher education(Shi, 2013). Since 2010 many colleges and universities have provided entrepreneurial courses for students mostly as optional ones, with more labs available for entrepreneurial activities. In addition several local governments implemented more specific policies such as financial funding to support the development of EE at local higher education institutions(Zhong, 2015). This commitment and policy support has had positive effects. Data collected from 486 universities in 2014 indicates that nearly 60,000 venues have been built and in operation for hands-on teaching and learning. During the 12th five-year plan(2011-2015), the central government, local governments and higher education institutions have financed 80,000 projects covering 12 disciplines with capital input of 1.4 billion Yuan(210 million USD) and with nearly 220,000 students' participating in some form of $\mathrm{EE}$ (Xue, $\mathrm{Lu}, \& \mathrm{Li}, 2016$ ).

\section{New Trends in China's EE}

It is evident from the above that $\mathrm{EE}$ in China is a priority of the Chinese central government and its related policies. Made In China's strategy is not merely a blueprint for economic development, it will significantly impact on China's entrepreneurship education in the coming decade and beyond. Current, trends in China's EE focus on the development of entrepreneurial environment and the scale for related training, technological innovation orientation, as well as increasing cooperation between academic institutions and enterprises.

\subsection{More Favorable Environment for Entrepreneurship Education}

Made In China 2025 is a framework for building an environment for the development of EE. In the framework for an entrepreneurial environment developed by Devi R. Gnyawali and Daniel S. Fogel (1994), government policies and procedures, socioeconomic conditions, entrepreneurial and business skills training, financial and non-financial assistance, including government procurement programs for small businesses, government support for research and development, tax incentives and exemptions are the key dimensions of an entrepreneurial environment (Gnyawali \& Fogel, 1994). Made In China 2025 sets tangible economic goals as well as systematic measures to support realization of its stated goals. As a ten-year national plan it lays out a range of society aspects and measures to help guarantee its successful implementation. These measures include: additional government reforms, building a market environment for fair competition in businesses, fiscal and tax support for enterprises, especially SMEs, and optimizing the entrepreneurial training system. The measures will have significant impacts on enterprises and entrepreneurial activities in China. In addition, Made In China 2025 highlights key elements that will promote the scale of entrepreneurship education, including entrepreneurial skill and management training within enterprises, as well as technical and engineering talent training in higher educational institutions. In combination these elements will result a more favorable environment for EE.

\subsection{Innovation Is Put at the Heart of China's EE}

Innovation in education and training will be at the heart of the development and implementation of EE in enterprises and higher education. In May, 2015 the State Council of the PRC issued Opinions On Further Reform Innovation and Entrepreneurship education in Higher Education Institutions (General Office of the State Council of the People's Republic of China, 2015). This document outlines the central government's expectation that higher education institutions will take major responsibilities for cultivation of entrepreneurial innovative talents. To meet current demand for innovation-driven development patterns for The New Normal economy, innovations in education are needed. To a large degree China's higher educational system still remains under the influence of a planned economy orientation, despite changes in college admission and job placements during the late 1990s. Many central government documents, since1998, have emphasized the importance for innovation and new ways of doing things to be integrated into entrepreneurship education (Tong, 2012; Shi, 2013), Many factors make it difficult for the idea of innovation in education to enter and change the existing test-oriented educational system (Tong, 2012). It is worth noting, however, that one of the guiding principles of Made In China 2025 is that "development of manufacturing should be driven by innovation" (MOF, 2015, chapt.2, para.2). Innovations in core manufacturing techniques, including product design and manufacturing systems require new approaches to meet the needs of a rapidly changing society. Innovative talents should be personnel who have innovation training and capability, and are experts with both professional and entrepreneurial skills. Given this, EE in China has to become innovation oriented in order to train innovative workers, engineers and managers for 
manufacturing businesses. The Made In China 2025 plan stresses that innovation must be integrated into EE, including curriculum design, and student entrepreneurial activities which may initiate a further reform of China's educational system, especially in the higher education sector.

In May 2014, Chinese President Xi Jinping put forward a strategy of "Building Shanghai into a Globally Influential Science and Technology Innovation Center" (Sina, 2015, para.1). Innovation in education will become increasingly critical to the central government focus on innovation in economy, science and technology. Innovation and its close alignment with entrepreneurship education have been the focus of several large international summits on entrepreneurship education, e.g. the International Forum on Innovation and Entrepreneurship Education hosted by Renmin University of China, October, 2015 and the International Innovation and Entrepreneurship Education Conference held recently in Shenzhen in June, 2016. A number of leading Chinese universities such as Tsinghua, Fudan and Sichuan Universities are committed to exploring effective ways to integrate innovation with EE in course design, teaching and learning methods, entrepreneurial supportive platform et al., which is shown as in the following table.

\begin{tabular}{|c|c|c|}
\hline $\begin{array}{l}\text { higher } \\
\text { education } \\
\text { institution }\end{array}$ & I\&E course, teaching and learning method innovation & $\begin{array}{l}\text { I\&E incubator and } \\
\text { platform }\end{array}$ \\
\hline $\begin{array}{l}\text { Tsinghua } \\
\text { University }\end{array}$ & $\begin{array}{l}\text { Challenge Based Learning, and } 15 \text { Challenge Based Model } \\
\text { Courses, } 20 \text { online entrepreneurial courses; } 2 \text { general education } \\
\text { courses }\end{array}$ & $\begin{array}{lr}\text { X-lab(an } & \text { online } \\
\text { innovation } & \text { and } \\
\text { entrepreneurship } \\
\text { education } & \text { center); } \\
\text { iCenter(a } & \text { maker } \\
\text { space); } & \text { Challenge } \\
\text { Cup I\&E Competition }\end{array}$ \\
\hline $\begin{array}{l}\text { Fudan } \\
\text { University }\end{array}$ & $\begin{array}{l}\text { general education core course system; 35interdisciplinary I\&E } \\
\text { courses; flexible semester system; }\end{array}$ & $\begin{array}{lr}\text { Financial support for } \\
\text { undergraduate } \\
\text { academic } & \text { research } \\
\text { plan; } & \text { youth } \\
\text { innovation } & \text { center; } \\
\text { college } & \text { student } \\
\text { business } & \text { start-up } \\
\text { parks } & \end{array}$ \\
\hline $\begin{array}{l}\text { Sichuan } \\
\text { University }\end{array}$ & $\begin{array}{l}\text { Ten thousand course plan; small class teaching; hands-on and } \\
\text { international courses; double tutorial system; hands-on and } \\
\text { international course week }\end{array}$ & $\begin{array}{l}3+3+\mathrm{N} \text { I\& } \mathrm{E} \\
\text { academy; } ¥ 1 \text { billion } \\
\text { corporate fund ; } \\
¥ 100 \text { million I\&E } \\
\text { fund; entrepreneurial } \\
\text { business street }\end{array}$ \\
\hline
\end{tabular}

Data collected from websites of Chinese Government, MOE, Sichuan University, and Fudan University.

\subsection{STEM Disciplines Become Pivotal in EE of China}

As a result of Made In China 2025 STEM disciplines will become more involved in EE and higher education institutions will take major responsibilities to cultivate student talents in STEM disciplines. Made In China 2025 signals that China will become a powerful manufacturing state and internationally competitive with developed countries in the West. This goal requires well trained human capital in the fields of science, technology, engineering and mathematics (STEM), as well as in entrepreneurship. Traditionally China's EE was embedded in business management education in part due to the fact that business schools and MBA programs starting in the 1990s were unprecedentedly popular especially among managers, business owners and CEOs. With the increasing demand for trained human capital in the manufacturing sector, training creative talents in STEM subjects will become the major focus for higher education institutions. One month after the Fourth Session of the 12th National People's Congress and the Chinese People's Political Consultative Conference held in March 2016, members of the Standing Committee of the Political Bureau including Xi Jinping, Li Keqiang, Liu Yunshan and 
Zhang Gaoli visited Tsinghua University, Beijing University, University of Science and Technology of China, Xi'an Jiaotong University, Chang'an University, Sichuan University, Central South University, and National Defense University PLA China. In such a short time span, China's top leadership's visit to universities that are noted for their STEM disciplines further supports and clarifies the central government's mandate to encourage entrepreneurial talent training in scientific and technological fields. The trend for STEM disciplines gaining more priorities in entrepreneurship education is also revealed in various entrepreneurship competitions during 2015-2016, e.g. computer and information technology was the theme of China Internet Plus College Student Innovation and Entrepreneurship Competition, which was held by MOE in 2015. The fifth China Innovation \& Entrepreneurship Competition 2016 initiated by MOE, MOF and MOST( Ministry of Science and Technology) in 2016 contained six high-tech fields closely relevant to STEM disciplines, such as technical engineering, internet, electronic information, new energy and environment conservation, new materials, and biomedicine. These high-tech fields are mandated in Made In China 2025 as key sectors to drive the manufacturing upgrading.

\subsection{EE Will Include All College Students}

Previously, EE tended to be elite education open only to selected students and in select colleges (Shi, 2013; Wang; Hou, 2014). Since the late 1980s and all through the 1990s and the first decade of the 21st century, entrepreneurship education has been the privilege or advantage purview of select top research universities (Zheng \& Liu, 2013; Guo, Sui, \& Han, 2014). A current goal for Made In China 2025 is that EE will become inclusive instead of elite education. Made In China 2025 articulates the importance and necessity for ALL higher education institutions, no matter what type, scale or ranking, to develop disciplines and courses related to entrepreneurship education. Made In China 2025 proposes a multi-level training system to build the human resources needed for the manufacturing upgrading. The training includes entrepreneurial training at the university level for personnel management, advanced professional and engineering experts, and entrepreneurial and vocational skill training in two-year or three-year colleges. These aims are to improve entrepreneurial skills in all levels within different agencies, therefore, entrepreneurship education will become a diversified and integrated mainstream education replacing the elite entrepreneurship programs for privileged groups. On December 11, 2015, the MOE issued Notice on Work for Employment and Entrepreneurship of the College Graduates in 2016 (MOE, 2015). It requires that all higher institutions should provide compulsory and optional courses on innovation and entrepreneurship education to all students whose performance in these courses should be included into the credit assessment system. This is in response to the central government's strategic call for more innovative talents for the manufacturing sector. The innovation-driven development strategy will boost EE to increasingly wider and deeper areas of the society.

\subsection{Cooperation between Enterprises, Education and Research Institutions Will Be Enhanced}

Finally, Made In China 2025 highlights the importance of cooperation between enterprises, education and research institutions by improving the talent education and training to support the successful manufacturing upgrading (MOF, 2015). Cooperation among enterprises, universities and scientific research institutions as an effective means to promote the commercialization of scientific research achievement has been proposed since the late1990s (Zhou, 2006). However, due to influence of the planned economy system, cooperation among the three parties encountered many problems from financing to system operations (Zhou \& Li, 2009), and faded from public attention. Made In China 2025, again stresses the importance of the cooperation between the three players from an economic perspective. Manufacturing upgrading requires significant human capital, experts in enterprise management, technology and engineering who have entrepreneurship training and expertise. To meet this duel demand it is essential to strengthen the ties between business, research centers and higher education institutions, which are critical factors in the practice of EE. In June 2015 IEEAC - Innovation and EE Association of China was founded at Tsinghua University. The founding members of this association include 137 universities and world renowned enterprises, such as Intel, Microsoft, Tencent, Baidu and Alibaba, as well as some non-profit organizations. This event signals a new page in the process of development of EE by shared resources and platforms including higher education, business enterprises, research centers and other organizations. Undoubtedly, the government plays a key role in such events and the implementation of Made In China 2025 will drive more similar concrete cooperations.

\section{Summary and Conclusion}

Economic reforms and the opening up of China, from 1978 to present day, has resulted in China becoming the second largest economy in the world. During the 30 plus years of progress the Chinese central government has issued and passed numerous policies and even laws to meet specific need and situations during different historic stages. Made In China 2025 is a historically significant five-year plan that was unveiled in 2015 and 
demonstrates Chinese top leadership's commitment to further economic reforms and upgrading of the manufacturing sector to world-class status. A comparative analysis of China's past and present economic reform policies with respect to EE is the focus of this article. EE, is at a new stage in the educational system reforms in China, and is expected to contribute to economic development and reshaping of the new manufacturing sector by providing enhanced human capital resources with innovative and entrepreneurial capabilities. However, due to the legacies of the previous planed economic systems, the development of EE encountered challenges and bottlenecks which impede its progress and even blur its future direction. To address previous difficulties Made in China 2025 outlines measures for enterprises and EE; e.g. supportive fiscal and tax policy, talent training through cooperation among businesses, education institutions and research centers. The Chinese central government policies have always had great impacts on and historically directed education reform in China. China's EE initiative is also "government-driven"(Yan, 2011, p.45). The proposed manufacturing upgrade goal to a world manufacturing superpower requires new directions for China's EE and training programs in the coming ten years, proposed changes including the transition of EE and training from an elite privilege to its integration across all sectors of higher education with an emphasis on the STEM disciplines. The proposed educational changes will place China's EE on a sound footing that will serve current economic system reform needs. As the implementation of Made In China 2025 occurs there will certainly be changes arising within EE, however, the central goal for EE as outlined in the Made In China 2025 strategic plan will likely remain the same: the production of more qualified human resources for economic and social development of China in the new world order.

\section{References}

Asia Unhedged. (2016). China's manufacturing sector expands for 1st time in 9 months. Retrieved May 20, 2016, from http://atimes.com/2016/04/chinas-manufacturing-sector-expands-for-1st-time-in-9-months/

Cao, Y. (2012). College Student's Starting Enterprises and Enterprise Education in the Context of Transitional Period of Economic Development Mode. Journal of Northeast Normal University (Philosophy and Social Sciences), 4, 234-237

Chinese Academy of Sciences. (2015). China Sustainable Development Report 2015. Retrieved July 23, 2016, from http://www.ipm.cas.cn/zss30zn/cghc/xlbg/201505/t20150514_4355614.html

Chuan, J. (2016). 6.9\% GDP Growth of China in 2015, the Lowest in 25 Years. Retrieved July 26, 2016, from http://www.bbc.com/zhongwen/simp/china/2016/01/160119_china_economy_gdp

Deloitte. (2016). Global Manufacturing Competitiveness Index. Retrieved July 22, 2016, from http://www2.deloitte.com/cn/zh/pages/manufacturing/articles/2016-global-manufacturing-competitiveness-i ndex.html

Editorial Board of China national Sustainable Development, China Sustainable Development Report 2015. $\begin{array}{llll}\text { Retrieved July } & 11, & 2016, & \text { from }\end{array}$ http://www.china.com.cn/zhibo/zhuanti/ch-xinwen/2012-06/01/content_25541073.htm

Fan, L. (2016). Innovation and Entrepreneurship Education: Breakthrough of Comprehensive Higher Education Reform. Retrieved April 22, 2016, from http://sei.shufe.edu.cn/qy/zjsd/1725.htm

General Office of the State Council of the People's Republic of China. (2015). GOSC's Opinions on Further Reform Innovation and Entrepreneurship education in Higher Education Institutions. Retrieved June 16, 2016, from http://www.gov.cn/zhengce/content/2015-05/13/content_9740.htm

Gnyawali, D. R., \& Fogel, D. S. (1994, July). Environments for Entrepreneurship Development, Key Dimensions and Research Implications. Entrepreneurship Theory and Practice, 43-62.

Guo, W., Sui, H., \& Han, S. (2014). Analysis and Measure of Current Situation of Innovation and Entrepreneurship Education in Regular Institutions of Higher Learning. Heilongjiang Education (Higher Education Research \& Appraisal), 2, 52-53

Gao, Y. (2015). Blueprint to boost manufacturing competitiveness. China Daily. Retrieved from http://english.gov.cn/policies/policy_watch/2015/05/20/content_281475111208079.htm

He, H. (2012). Strategy for the Development of College Student Entrepreneurship Education from the Perspective of Entrepreneurial Economy. Education Exploration, 7, 151-153

Huang, Z., \& Zhao, G. (2015). Comparative study on Entrepreneurship Education Curriculum System in Chinese and American higher education institutions. China Association of Higher Education, 8, 2-5. 
Huang, Z. (2007). Study on China's Economic Cycle and Macro-control Efforts in 30 Years of Reform and Opening-up. Journal of Finance and Economics, 34(11), 88-100.

Jin, B. (2015). Study on the New Normal of Chinese Economic Development. China Industrial Economics, 1, 5-18.

Li, J., \& Liu, F. (2009). The Development, Challenges and Measures of Entrepreneurship Education in Chinese Higher Education Institutions. Journal of China Youth College for Political Sciences, 5, 1-5.

Li, J., Zhang, Y., \& Matlay, H. (2003). Entrepreneurship Education in China. Education and Training, 11, 495-505. https://doi.org/10.1108/00400910310508883

Li, S., Wu, S., He, J., \& Liu, M. (2012). Review and Prospect of China's Economy after Accession to the WTO Ten Years. Journal of Beijing Institute of Technology (Social Sciences Edition), 14(3), 1-8.

Li, X. (2009). Problems and Measures of Industry-University-Research Cooperation in Universities. Chinese University Technology Transfer, 11, 50-51.

Liang, Y. (2014). The Text Study of Deng Xiaoping's Southern Talk (Master's thesis, Zhejiang Sci-tech University, Hangzhou, China). Retrieved from http://202.38.93.12/KNS55/brief/result.aspx

Liu, F., Xu, L., \& Liu, C. (2007). The Commence, Development and Challenge of Chinese Entrepreneurship Education. China Youth Study, 9, 5-9.

Liu, H., \&Jia, W. (2011). Preface to Twenty Years of Chinese Entrepreneurship Education. Journal of Anhui University of Science and Technology, 13(4), 79-82.

Liu, Y. (2010). The Development and Reflection of Chinese Higher Education 60 years after the Building of the New China. China Electronics Education, 1, 1-6.

Ministry of Education of the People's Republic of China. (1985). The Decision of the CPC Central Committee on Educational System Reform. Retrieved April 10, 2016, from http://www.moe.gov.cn/jyb_sjzl/moe_177/tnull_2482.html

Ministry of Education of the People's Republic of China. (1998). The 1999 Chinese Action Scheme For Invigorating Education Towards The 21st Century. Retrieved June 4, 2016, from http://www.moe.gov.cn/jyb_sjzl/moe_177/tnull_2487.html

Ministry of Education of the People's Republic of China. (2010). Opinions About Vigorously Promoting Innovation and Entrepreneurship Education and Self-Employment in Higher Education Institutions. Retrieved May 11, 2016, from http://www.moe.gov.cn/srcsite/A08/s5672/201005/t20100513_120174.html

Ministry of Education of the People's Republic of China. (2012), Retrieved May 10, 2016, from http://www.moe.edu.cn/publicfiles/business/htmlfiles/moe/s7056/201301/146673.html

Ministry of Education of the People's Republic of China. (2015). Notice on Work for Employment and Entrepreneurship of the College Graduates in 2016. Retrieved May 17, 2016, from http://www.moe.edu.cn/srcsite/A15/s3265/201512/t20151208_223786.html

Ministry of Finance of the People's Republic of China. (2015). The State Council's Notice on Issuing Made In China 2025. Retrieved May 7, 2016, from http://www.mof.gov.cn/zhengwuxinxi/zhengcefabu/201505/t20150519_1233751.htm

News of the Communist Party of China. (1992). The Decision of The Central Committee of The Communist Party of China and The State Council on Accelerating Development of Tertiary Industry. Retrieved June 10, 2016, from http://cpc.people.com.cn/GB/64162/64165/65856/4454474.html

Orszag, P. R. (2014). Private Companies Are Driving China's Growth. Retrieved March 16, 2016, from http://www.bloomberg.com/view/articles/2014-10-14/private-companies-are-driving-china-s-growth

Sina. (2015). Building Shanghai into a Globally Influential Science and Technology Innovation Center. Retrieved July, 15, 2016, from http://news.sina.com.cn/zhiku/zjgd/2015-08-10/doc-ifxftvni8899263.shtml

Shi, J. (2015). Announcement for Translation of Important Terminology of Central Government's Document. Retrieved May 20, 2016, from http://www.cctb.net/bygz/zywxsy/201504/t20150427_321849.htm

Shi, Y. (2013). Research on Ten-year development of Chinese Entrepreneurship Education in Higher Education Institutions. China Higher Education Research, 4, 69-73.

Taplin, N., \& Sweeney, P. (2016). China official factory activity unexpectedly expands but job losses mount. 
Retrieved May 9, 2016, from http://www.reuters.com/article/us-china-economy-pmi-idUSKCN0WY39U

The State Council Information Office of the People's Republic of China. (2016). Press Conference on Economic and Social Development 2015. Retrieved March 11, 2016, from http://www.scio.gov.cn/xwfbh/xwbfbh/wqfbh/33978/34138/wz34140/Document/1467212/1467212.htm

Tong, X. (2013). Research on Innovation and Entrepreneurship Education System of Research University (Doctoral dissertation, Wuhan University of Technology, Wuhan, China). Retrieved May 10, 2016, from http://202.38.93.12/KNS55/brief/result.aspx

Trentini, M. (2015). "Made in China 2025" - Chinese Industrial Ambitions. Retrieved March 8, 2016, from http://themarketmogul.com/made-in-china-2025-chinese-industrial-ambitions/

Wang, H. (2015). China Has the Largest Population of College Undergraduates, and students number from poverty-stricken areas rises. Retrieved April 11, 2016 from http://inews.ifeng.com/yidian/46526729/news.shtml?ch=ref_zbs_ydzx_news

Wang, Y. (2015). Reflection on Innovation and Entrepreneurship Education and Mode Construction in Higher Education Institutions. China University Teaching, 4, 4-7.

Wang, Z., \& Hou, Y. (2014). Research on the Misunderstanding of Entrepreneurship Training for University Students and the Relevant Approaches. Journal of South China Normal University (Social Science Edition), $8,69-72$.

Wu, L. (2009). Review of New China's Economic Development for 60 Years. Journal of Jiangsu Administration Institute, 6, 37-42.

Xiong, F., \& Qiu, W. (2005). Comparison of Entrepreneurship Education between China and the United States. Journal of Beijing University of Aeronautics and Astronautics (Social Sciences Edition), 18(4), 73-78.

Xue, C., Lu, C., \& Li, D. (2016). Reflection on Innovation and Entrepreneurial Education in Universities during 12th Five-Year-Plan Period - Analysis based on The Report of Chinese Higher Education Accreditation by Third Party. China Higher Education Research, 2, 20-28.

Yan, M. (2011). Government-driven Entrepreneurship Education: The Process and Cause of College Student Entrepreneurship Education in China. China Higher Education Research, 3, 45-48.

Zhang, D., \& Liu, H. (2013). Policy Instrument Application in Chinese Higher Education Reform. Fudan Education Forum, 11(1), 50-54.

Zhao, Y. (2012). Theoretical and Empirical Study of SME Development and Employment Growth(Master's thesis, Henan University, Kaifeng, China). Retrieved May 12, 2016, from http://202.38.93.12/KNS55/brief/result.aspx

Zheng, Z. (2013). Analysis of Current Situation and Measure Research on College Student Innovation and Entrepreneurship Education. North Economy and Trade, 1, 110-115.

Zhong, R. (2015). Problems and Strategies of Innovation and Entrepreneurship Education of Colleges and Universities during the Transitional Period. Academic Exploration, 4, 152-156.

Zhou, Yi. (2006). Reflection on Development Direction of Industry-University-Research Cooperation in China. China Higher Education Research, 8, 55-56.

\section{Copyrights}

Copyright for this article is retained by the author(s), with first publication rights granted to the journal.

This is an open-access article distributed under the terms and conditions of the Creative Commons Attribution license (http://creativecommons.org/licenses/by/4.0/). 